\title{
Process Approach and Organizational Change on the Example of Transport and Logistics System
}

\begin{abstract}
Protasova L.G.
Ural State University of Economics, Ekaterinburg

"Corresponding author. Email: protasova.mila@mail.ru

ABSTRACT

The article focuses on the use of the process approach in carrying out organizational changes. The work explores the approaches of various authors to the implementation of organizational changes, as well as statistical data on freight transportation by rail in 2000-2018 in Russia. Processing the results using the Shekhart control charts revealed violations of the stability and controllability of the processes of cargo transportation in the transport and logistics system of Russian Railways in 2009 and 2010. The external and internal causes are analyzed, the problems that do not ensure the rapid development of the industry are summarized. A process approach to organizational changes in the management structure of Russian Railways based on the standards of the GOSTR ISO 9000 series is proposed. An approach to the development of a responsibility matrix for the life cycle processes of the Company's products (services) is demonstrated. This will ensure the achievement of the stated goal of the company to reduce non-productive costs, due to efficient process management, lowering inter-functional barriers, preventing stability and controllability of cargo transportation processes in the transport and logistics system of Russian Railways.
\end{abstract}

Keywords: rail freight, statistics, Shekhart control charts, organizational changes, process approach

\section{INTRODUCTION}

The contribution of the Russian railway logistics system (LS) to the country's economy is difficult to overestimate. The infrastructure component in a market economy should develop stably, dynamically and at a faster pace. The organization of JSC Russian Railways is in fact a natural monopoly, but still an open system, influenced by factors of the external and internal environment [10]. The author [7], answering the question of how an enterprise can withstand changes in the external environment (occurring often, but irregularly and almost unpredictably), notes that management should constantly monitor the main components of the environment and draw conclusions about its needs for changes, proposing to use methods change management. In [3], it is noted that in 2016 changes were made in the field of improvement and development of the management system of JSC Russian Railways, particular attention was paid to determining and optimizing the distribution of powers and responsibilities of heads of structural divisions of functional branches at all levels of management and introducing a process approach. It is necessary to evaluate the effectiveness and efficiency of the implementation of organizational changes. Is the goal achieved and the expected result achieved?

In the work of V. Demyanenko [2], it is noted that in the desire to increase the effectiveness of changes carried out in organizations within the framework of strategic projects, quality management, staff development, and efficiency improvement, two areas have been identified that cause wide discussion. Some experts (Hersey, Blankkhard) believe that in the first place it is necessary to change the attitude of employees, andas a result their behavior will change. Others (Bier, Eiseynstat, Spector) argue that the most effective way is to place employees in new conditions (organizational changes) that will facilitate the reallocation of roles, the emergence of new responsibilities and relationships. The author's practical experience [2] shows that a positive result of organizational changes in Russian companies is achieved if managers emphasize the introduction of new conditions that shape new personnel behavior. Which is also consistent with the concept of E. Deming on improving the system as a whole within the framework of system and process approaches [7].

The purpose of the study is to identify instabilities in the transport and logistics system of railway transportation of Russia, to develop measures to eliminate them, to carry out organizational changes based on the process approach at JSC Russian Railways to restore stability and manageability in the transport and logistics system.

The methodology of research and design changes in the organization is based on different methods, in particular, on a system and process approach. The first allows you to take into account many factors and highlight the most significant of them. In the West, the methodology of eight stages by J. Cotter gained great popularity, which is based 
on the idea of involving employees in the work of transforming the company by popularizing the picture of the future organization [2]. But, as you know, people love constancy, and so that they canalso change quickly, it is necessary to apply the new principle of constancy - this is the constancy of change for the better [6].

This study aims to reduce the variability of the system and the process in order to increase the stability and predictability of organizational changes conducted by management. The tasks were to identify variability in the transport and logistics system of railway transportation in Russia using Shekhart control charts [6], and propose organizational changes to restore stability in the system.

Change is due to innovation, and innovation is known to require investment. It has already been proven that the effectiveness of investments in science, education, infrastructure, management and informatization is quite high, according to the authors of [8], it is on average seven.

\section{MATERIALS AND RESEARCH METHODS}

Statistical data on freight transportation by rail in 20002018. in Russia served as factual material for the study. Data was processed using Shekhart control charts.

Despite the fact that statistical control of processes originated in production, it can be used to control business processes in organizations providing services, in particular, transport and logistics. The main goal is to detect instability in the process, to determine the causes of variability and the need for changes. Shekhart control charts (CCS) have long been used in the West as a means of monitoring process stability. The authors of [9] give examples of the use of the Shekhart Control Charts (CCS) for analyzing the trade deficit in the United States, and the results showed that the process is stable, predictable and in a statistically controlled state. However, management mistakenly spent resources on analyzing trends, searching for reasons due to a misinterpretation of variations.

In this paper, we will use control charts of individual values and a moving range (XmR card) [4]. The sliding range is the modulus of the difference of successive $\mathrm{X}$ values. For an XmR map, the boundaries are calculated using the following formulas [17].

Upper border of $U N P L_{X}$ is calculated by formula (1) $U N P L_{X}=\bar{X}+d_{2} \overline{m R}$ (1)

где $\bar{X}$ - average value of the parameter, $d_{2}-$ multiplier, $\overline{m R}$ - average range.Centre line $C L_{X}$ is calculated by formula (2) $C L_{X}=\bar{X}(2)$

Lower border $L N P L_{X}$ is calculated by formula (3) $L N P L_{X}=\bar{X}-d_{2} \overline{m R}(3)$

Upper border of $U C L_{R}$ is calculated by formula (4) $U C L_{R}=$ $D_{4} \overline{m R}$ (4) $D_{4}$-multiplier

The rules for interpreting the results obtained, if the $\mathrm{X}$ values are within the upper and lower boundaries of the map and are evenly located relative to the center line of the map, then the process is in a statistically controlled state. If the values are out of bounds, then the process is in a statistically uncontrolled state.

Statistical Process Management (SPC) is a good management tool designed for continuous monitoring and diagnostics of business processes [4].

\section{RESEARCH RESULTS AND DISCUSSION}

To construct Shekhart maps, we used the xls program and statistical data on railway freight transportation in Russia from 2000 to 2018 (Fig. 1) according to [12,13]. These data are not subject to grouping, therefore, we use maps of individual values and a sliding range(XmR-map)[5].

ForXmR-mapboundaries are calculated according to formulas (1-4) above where $\overline{m R}$ - average range, and the multipliers $d_{2}$ и $D_{4}$ are 3.267 и 2.660 accordingly [17]. Based on the calculation results, Shukhart's control charts were constructed for the railway freight traffic of Russian Railways (Diagram 1) and the rolling range (Diagram 2) from 2000 to 2018.

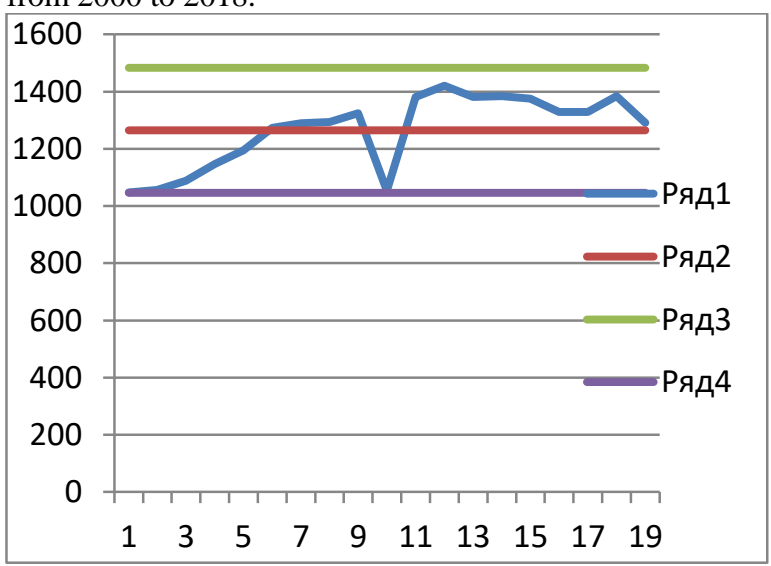

Diagram 1 The control card of cargo transportation byrail from 2000 to 2018 , million tons

Line 1-freight transportation, mln tons

Line 2-average range

Line 3-upper border

Line 4-lower border

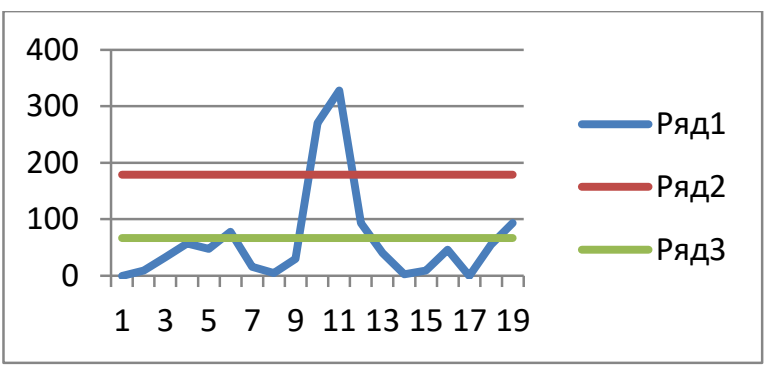

Diagram 2 The control map of the moving range from 2000 to 2018, million tons of the product life cycle of the company 
Table 1 The matrix of responsibility for the processes

\begin{tabular}{|c|c|c|c|c|c|c|c|c|c|}
\hline $\begin{array}{l}\text { Processes/ } \\
\text { Executives }\end{array}$ & $\begin{array}{l}\text { Deputy } \\
\text { CEO }\end{array}$ & $\begin{array}{l}\text { First } \\
\text { Deputy } \\
\text { General } \\
\text { Director } \\
\text { of } \\
\text { Strategic } \\
\text { Develop } \\
\text { ment, } \\
\text { Corpora } \\
\text { te } \\
\text { Governa } \\
\text { nce, } \\
\text { Economi } \\
\text { cs and } \\
\text { Finance }\end{array}$ & $\begin{array}{l}\text { First } \\
\text { Deputy } \\
\text { General } \\
\text { Director } \\
\text { (general } \\
\text { manage } \\
\text { ment \& } \\
\text { coordinat } \\
\text { ion of } \\
\text { productio } \\
\text { n and } \\
\text { business } \\
\text { activities } \\
\text { of the } \\
\text { company } \\
\text { ) }\end{array}$ & $\begin{array}{l}\text { Deputy } \\
\text { General } \\
\text { Director } \\
\text { (commer } \\
\text { cial } \\
\text { activities } \\
\text { of the } \\
\text { company } \\
\text { and } \\
\text { freight } \\
\text { transpor } \\
\text { tation) }\end{array}$ & $\begin{array}{l}\text { Deputy } \\
\text { General } \\
\text { Director } \\
\text { (passeng } \\
\text { er } \\
\text { complex } \\
\text { ) }\end{array}$ & $\begin{array}{l}\text { Deputy } \\
\text { General } \\
\text { Director } \\
\text { - Head } \\
\text { of the } \\
\text { Central } \\
\text { Director } \\
\text { ate of } \\
\text { Infrastr } \\
\text { ucture }\end{array}$ & $\begin{array}{l}\text { Deputy } \\
\text { General } \\
\text { Director } \\
\text { - Head } \\
\text { of } \\
\text { Traffic } \\
\text { Safety } \\
\text { Departm } \\
\text { ent }\end{array}$ & $\begin{array}{l}\text { Deputy } \\
\text { General } \\
\text { Director } \\
\text { for } \\
\text { Internal } \\
\text { Control } \\
\text { and } \\
\text { Audit }\end{array}$ & $\begin{array}{l}\text { Chief } \\
\text { Account } \\
\text { ant }\end{array}$ \\
\hline Marketing & $\mathrm{R}, \mathrm{E}$ & & & & & & & $\mathrm{P}$ & $\mathrm{P}$ \\
\hline Planning & $\mathrm{P}$ & $\mathrm{R}, \mathrm{E}$ & $\mathrm{P}$ & $\mathrm{P}$ & $\mathrm{P}$ & $\mathrm{P}$ & $\mathrm{P}$ & & $\mathrm{P}$ \\
\hline $\begin{array}{l}\text { Procureme } \\
\text { nt }\end{array}$ & & $\mathrm{P}$ & $\mathrm{R}, \mathrm{E}$ & $\mathrm{P}$ & $\mathrm{P}$ & $\mathrm{P}$ & $\mathrm{P}$ & & $\mathrm{P}$ \\
\hline $\begin{array}{l}\text { Freight } \\
\text { Carriages }\end{array}$ & $\mathrm{P}$ & $\mathrm{P}$ & $\mathrm{P}$ & $\mathrm{R}, \mathrm{E}$ & & $\mathrm{P}$ & $\mathrm{P}$ & $\mathrm{P}$ & $\mathrm{P}$ \\
\hline $\begin{array}{l}\text { Passenger } \\
\text { Transporta } \\
\text { tion }\end{array}$ & $\mathrm{P}$ & $\mathrm{P}$ & $\mathrm{P}$ & & $\mathrm{R}, \mathrm{E}$ & $\mathrm{P}$ & $\mathrm{P}$ & $\mathrm{P}$ & $\mathrm{P}$ \\
\hline $\begin{array}{l}\text { Infrastruct } \\
\text { ure }\end{array}$ & & $\mathrm{P}$ & $\mathrm{P}$ & $\mathrm{P}$ & $\mathrm{P}$ & $\mathrm{R}, \mathrm{E}$ & $\mathrm{P}$ & & $\mathrm{P}$ \\
\hline Security & & & $\mathrm{P}$ & $\mathrm{P}$ & $\mathrm{P}$ & $\mathrm{P}$ & $\mathrm{R}, \mathrm{E}$ & $\mathrm{P}$ & $\mathrm{P}$ \\
\hline $\begin{array}{l}\text { Quality } \\
\text { control }\end{array}$ & $\mathrm{P}$ & $\mathrm{P}$ & $\mathrm{P}$ & $\mathrm{P}$ & $\mathrm{P}$ & $\mathrm{P}$ & $\mathrm{P}$ & $\mathrm{R}, \mathrm{E}$ & $\mathrm{P}$ \\
\hline $\begin{array}{l}\text { Efficient } \\
\text { use of } \\
\text { finance }\end{array}$ & & & & & & & & & $\mathrm{R}, \mathrm{E}$ \\
\hline
\end{tabular}


Line 1-rolling range, $\mathrm{mln}$ tons

Line 2- average range

Line 3- upper border

As can be seen in Diagram 1, the volumes of freight transported by rail from 2000 to 2004 are below the average, and starting from 2005, above the average line, with the exception of 2010 when the minimum value is observed. In general, we can conclude that the process is stable; the values lie between the upper and lower boundaries of the map, and are in a statistically controlled state.

However, Diagram 2 illustrates the moving values of the moving range beyond the boundaries of the upper control limit in 2009 and 2010, which indicates a violation of the stability and controllability of the process. Apparently, the influence of external factors related to the global economic crisis in 2008 and anti-Russian sanctions affected.

As can be seen in Diagram 1, in 2018 there is a decrease in freight traffic to an average value, we can assume the influence of already internal factors - stagnation in the Russian economy. Despite the financial support of this industry from the state, and the changes made by the management related to the increase in railway tariffs, the increase in the cost of renting cars [11], and the optimization of the management system [3], the changes did not ensure the industry was outstripped. In our opinion, the reason is that organizational changes at JSC Russian Railways were carried out within the framework of the traditional management model, taking into account the specialization of managers in areas and types of economic activity [3].

It is necessary to switch to a new management model quality management. The corporate quality management system at Russian Railways is currently at the design stage, however, objectives in the field of quality have been defined, including the systematic reduction of unproductive costs and increased profitability based on the introduction of a process approach and the formation of economic levers for managing internal processes of the Company [14].

To achieve the stated goal, we propose to build a management system based on a process approach, endowing managers with responsibility and authority over the processes. Today, the management structure of Russian Railways includes a general director, three first deputy general managers, eighteen deputy general directors, a chief accountant and a head of the legal department. You can start with the distribution of powers and responsibilities between them over the processes of the product and service life cycle (product life cycle) in a company [15]. To do this, we use the responsibility matrix - a quality management tool, where $\mathrm{R}$ is the responsible, $\mathrm{E}$ is the executor, $\mathrm{P}$ is the participant (Table 1).Using this tool allows you to optimize the company's activities through effective process management, efficient use of resources and reducing inter-functional barriers [16], since in each process there are not only responsible people and executors, but also participants who provide information, resources and the quality of their activities also depends processperformance.
Since specialization was not allocated to the Deputy General Director in the management structure, they identified a very important marketing process for him, from which the life cycle of products and services begins, including monitoring the market and consumer needs, since the company's future activities are planned on the basis of the results obtained [18]. Unfortunately, the structure did not have a head responsible for procurement, and this is also a very important process in the product life cycle, the purpose of which is to ensure uninterrupted supply of the company with all necessary material and technical resources. It is known that in the branches of JSC Russian Railways there is an acute shortage of wheels and other spare parts and components needed to repair locomotives and cars, in addition, there are no tools and devices for repairing new-generation railway cars, which may adversely affect the stability and controllability of processes TLS. We offer to provide responsibility and authority for the procurement process of the First Deputy General Director (general management and coordination of the production and business activities of the company). The chief accountant was also given the responsibility for the process of efficient use of financial resources. As can be seen from the table, in the matrix of responsibility there are many participants in each process, and only seven managers are involved in the product life cycle processes. Similarly, the rest of the managers in the management structure need to identify the appropriate processes.

\section{CONCLUSION}

In summary, when making decisions on organizational changes in the company, many factors should be taken into account: management, personnel, management structure, internal environment, external environment, economic, technological, information, innovation and investment environment and others. When developing the final version of the responsibility matrix, most managers will be assigned responsibility, and the executors will be their subordinates, however, it should be borne in mind that the matrix should not include managers who are only involved in the processes and do not act as the executor or the person responsible. The responsibility matrix is a good tool for optimizing the management structure, improving the quality, efficiency and effectiveness of management, if it is developed by the team, brought to the attention of managers and is in the public domain.

\section{REFERENCES}

[1] Alaev A. Application of Shekhart control charts for quantitative analysis of traffic (and any data in general). Marketing. 2018 // https://vc.ru/marketing/41825primenenie-kontrolnyh-kart-shuharta-dlyakolichestvennogo-analiza-trafika-i-lyubyh-dannyhvoobshche 
[2] Demyanenko V. Features of change management in Russia // Bulletin of Change Management.v.2 //http://ibcm.biz/?p=108

[3] Kachesova I.N., Tsevelev V.V. Organizational changes of the enterprise on the example of Russian Railways // Scientific forum: Economics and management: Sat. Art. based on materials of the XI int. scientific-practical conf. - No. 9 (11). - M., Ed. "ICNO", 2017. S. 36-45.

[4] Shekhart control charts and a probabilistic approach // www.deming.ru / TehnUpr / KontKartSh / hrm /

[5] Shekhart control charts. Rules for determining the lack of controllability. Logistics. 2011 // http: //baguzin.ru/wp/kontrolnye-karty-shuharta-pravila-op/

[6] Lapidus V. A. Top management on universal quality (TQM) and ISO standards 2000 version. Dialogue of the consultant with the head of the company / V. A. Lapidus, A. M. Rekshinsky. N. Novgorod: SMC "Priority", 2000.

[7] Norbert T. Change Management. Problems of the theory and practice of change //https://www.cfin.ru/management/change_management .shtml

[8] Ryazanov V.T. Opportunities and conditions for overcoming the stagnation of the domestic economy // Economist. 2015. No.6. S.3-18.

[9] Thomas W., Nolan and Lloyd P. Provost. Understanding Variation//Quality

Progress.May.1990.P.2-10.

[10] Change Management: Textbook / O.V. Leatherwork. - 2nd ed., Rev. and add. - M.: SIC INFRA-M, 2016 .-- 304 p.

[11]Protasova L.G, Zueva O.N.The contribution of transport logistics to the competitiveness of domestic products in the context of digitalization //Series:Advances in Economics, Business and Management Research Proceedings of the International Scientific and Practical Conference on Digital Economy (ISCDE 2019).v.105, p.390-395. https://www.atlantispress.com/article/125924628 ID - Protasova2019/12.

[12] Russia in numbers. 2016. Brief statistical compilation. M.: Rosstat. 2016-543s.

[13] Russia in numbers. 2019. A Brief Statistical Collection, Moscow: Rosstat. 2019-59s.

[14] Russian Railways OJSC http://www.rzd.ru
[15] GOST R ISO 9001-2015. Quality Management Systems. Requirements. M.: Standartinform. 2015. -22 p.

[16] GOST R ISO 9000-2015. Quality Management Systems. Fundamentals and vocabulary. - M : Standartinform, 2015 .- 48 p.

[17] GOST R ISO 7870-2-2015 Statistical methods. Control cards. Part 2. Control Shekhart cards. // URL: http://docs.cntd.ru/document/1200124585

[18] Gviliya N.A., Parfyonov A.V., Shulzhenko T.G. (2019). Managing integrated interorganizational logistic systems in the digital economy. Upravlenets The Manager, vol. 10, no. 1, pp. 40-51. DOI: 10.29141/2218-5003-2019-10-1-4. 